\title{
Cross-Border Insurance in Europe: Challenges for Supervision
}

\author{
Dirk Schoenmaker ${ }^{\mathrm{a}}$ and Jan Sass ${ }^{\mathrm{b}}$ \\ ${ }^{a}$ Department of Finance, Rotterdam School of Management, Erasmus University, Burgemeester Oudlaan 50, 3062 \\ PA, Rotterdam, The Netherlands. \\ E-mail: schoenmaker@rsm.nl \\ boliver Wyman, Fred. Roeskestraat 97E, 1076 EC, Amsterdam, The Netherlands.
}

At the start of Solvency II in January 2016, there is no overview of the insurance market in Europe. This paper develops a methodology to link various data sets on foreign branches and subsidiaries. The result is a new and comprehensive data set of cross-border insurance in Europe. We find that cross-border business in insurance is higher than in banking. We also find that the share of cross-border insurance has increased over the last decade, notwithstanding the global financial crisis. EIOPA, the European supervisory authority, plays a coordinating role among the national supervisors in the approval of internal models under Solvency II. Game theory suggests that there are limits to the coordination model. The increasing share of cross-border insurance, documented in this paper, may tilt the supervisory balance from coordination towards centralisation in an Insurance Union.

The Geneva Papers (2016) 0, 1-27. doi:10.1057/gpp.2015.35

Keywords: insurance markets; measures for internationalisation; level playing field; game theory; financial supervision

Article submitted 23 February 2015; accepted 24 November 2015; advance online publication, 10 February 2016

\section{Introduction}

While insurance is traditionally an international business, the degree of internationalisation is difficult to measure due to a lack of data. By contrast, cross-border banking and capital markets transactions are well documented, which supports both policymakers and business leaders in their decision-making. With the advance to Solvency II, the single market in insurance will be reinforced. The new common capital framework may also lead to market restructuring. ${ }^{1}$ Earlier examples of regulatory-driven market structuring are the adoption of the third life and non-life directives, which introduced the single market with home country control, and the introduction of the euro, both in the 1990s. The subsequent wave of intraEuropean consolidation was stronger in the insurance sector than in other financial sectors. $^{2}$

\footnotetext{
${ }^{1}$ Stoyanova and Gründl (2014).

${ }^{2}$ Berger et al. (1999).
} 
The new risk-based capital framework leaves room for supervisory interpretation and discretion (e.g. in the model-approval process or the application of capital add-ons in Pillar 2). Solvency II may thus give rise to level playing field discussions between the insurance industry and supervisors. ${ }^{3}$ A detailed overview of the market aids an informed debate about the materiality of level playing field issues. It also helps supervisors to assess the impact of Solvency II across Europe.

The aim of this paper is twofold. The first aim is to provide a comprehensive overview of cross-border insurance in Europe. The data sources on international insurance provide a scattered view of the European market. The European Insurance and Occupational Pensions Authority (EIOPA) publishes data on cross-border branches, while OECD Insurance Statistics provide an aggregate, albeit incomplete, overview of foreign subsidiaries. We complement these public data with supervisory data. The so-called colleges of supervisors, with representatives from the home country, host countries and EIOPA, enhance the consistent and effective supervision of European cross-border insurers. ${ }^{4}$ The Helsinki Protocol describes the required collaboration between European insurance supervisors in the group supervision of these insurance groups. As part of this group supervision, EIOPA has collected the "Helsinki list" of European insurance groups, with a detailed breakdown of branches and subsidiaries by country of the major insurers across the European Economic Area (EEA). In addition, EIOPA collects the "U.S. list" of European branches and subsidiaries of major U.S. insurers. ${ }^{5}$ We develop a methodology to link the Helsinki and U.S. data to the EIOPA data on foreign branches and OECD data on foreign subsidiaries. The result is a new and comprehensive data set of cross-border insurance in Europe.

The second aim is to examine whether cross-border insurance has been increasing since 2000. An increase of cross-border insurance would pose new coordination challenges for European supervisors. In the literature, gross written premiums (GWP) is used as dominant indicator for the geographical segmentation of insurance business. ${ }^{6}$ Our results show that cross-border insurance, measured by GWP, amounts to 36 per cent of total GWP in EU countries in 2012, while the comparable number for banking, measured by assets, stands at 25 per cent of total banking assets in EU countries. Moving from country to individual firm level, the results indicate that the 25 largest European insurers are very international, with 32 per cent of a large insurer's GWP in the rest of Europe and 27 per cent in the rest of the world. Again the large banks are less international, with 24 per cent of a large bank's assets in the rest of Europe and 23 per cent in the rest of the world. Our results confirm the international orientation of insurance found in earlier studies. ${ }^{7}$ Applying Tobit regressions, we find that the increase of crossborder insurance at the 25 largest European insurers is statistically significant over the 2000-2012 period.

\footnotetext{
${ }^{3}$ Starita and Malafronte (2014).

${ }^{4}$ Moshirian (2012).

${ }^{5}$ The Helsinki list and U.S. list data are confidential. We use data aggregated at country level, which cannot be related to individual insurance groups.

${ }^{6}$ For example, van der Zwet (2003); Schoenmaker et al. (2008).

${ }^{7}$ van der Zwet (2003); Focarelli and Pozzolo (2008).
} 
Insurance is thus more international than banking. Moreover, the internationalisation is rising. This raises the question whether there is a case for an Insurance Union following the Banking Union. Since the crisis, national supervisors, both in Europe and beyond, tend to require overcapitalisation of local subsidiaries. ${ }^{8}$ Insurance groups have thus pockets of capital locked up in the various jurisdictions in which they operate. Consolidated supervision, including centralised capital management, would be an argument in favour of centralised supervision. Another argument is the business practice of integrated asset management at large insurers. Next, some supervisors are no doubt tougher than other supervisors, also under the new harmonised Solvency II framework. ${ }^{9}$ Finally, game theory indicates that supervisors will not cooperate when interests diverge. ${ }^{10}$ A centralised supervisor may be an effective solution to improve supervision and address level playing field issues.

But on the other side, insurance is less subject to systemic risk and related externalities than banking. ${ }^{11}$ Cross-border externalities are the main reason for Banking Union. Moreover, insurance is largely local business, as products are attuned to local tax, social security and legal rules (e.g. liability law).

The paper is organised as follows. The next section reviews the literature on internationalisation. Next, we develop a systemic approach to link the various data sets and a methodology to test for an increase in internationalisation. The latter two sections present our results on the current state of cross-border insurance activities at the country level and at the firm level. We compare our results for Europe with the internationalisation in North America and Asia. The penultimate section discusses the supervisory challenges. Finally, the last section presents the conclusions.

\section{Methodology and data}

\section{Methodology}

In the literature, a variety of indicators are used to measure internationalisation. Research on the internationalisation of financial firms is extensive, but most studies focus on banks. ${ }^{12}$ At the country level, De Nicoló et al. ${ }^{13}$ measure internationalisation through foreign bank ownerships, that is, the amount of total assets in which foreign banks have an equity share of 50 per cent or more. Next, Claessens and van Horen ${ }^{14}$ define foreign bank presence as the number of foreign banks as a share of total banks in a country. Finally, Schoenmaker ${ }^{15}$ measures international banking by the amount of foreign lending as a share of total lending in a country.

\footnotetext{
${ }^{8}$ Cerutti and Schmieder (2014).

${ }^{9}$ Sironi (2002).

${ }^{10}$ Claessens et al. (2010); Schoenmaker (2011).

${ }^{11}$ Weiss and Mühlnickel (2014).

12 see Moshirian (2006), for an overview.

13 De Nicoló et al. (2004).

14 Claessens and van Horen (2014).

15 Schoenmaker (2013).
} 
At the firm level, early research focuses on non-financial institutions, but more recent papers also examine the degree of internationalisation of financial firms. A first line of research measures internationalisation for non-financial institutions by a single variable. ${ }^{16}$ Sullivan ${ }^{17}$ reviews 17 papers that research the measurement of internationalisation based on a single variable and finds that using only one single indicator increases the possibility of measurement errors. He recommends using a multidimensional measurement method, called the Trans Nationality Index (TNI), which is calculated as an unweighted average of (i) foreign assets to total assets, (ii) foreign income to total income and (iii) foreign employment to total employment. Next, Gulamhussen et al. ${ }^{18}$ establish a more complete set of measures, examining (i) the number of foreign countries in which a bank is active divided by the maximum number of foreign countries in which the most international active bank is active, (ii) the share of foreign assets and (iii) a transformed Hirsch-Herfindahl index that measures international concentration. However, Ramaswamy et al. ${ }^{19}$ find little support for Sullivan's findings and recommend the use of the dominant indicator in the respective industry.

As mentioned before, the internationalisation of the insurance industry has not been covered as extensively as that of the banking sector. Eppink and van Rhijn ${ }^{20}$ research the degree of internationalisation of several Dutch insurance companies by examining the geographic distribution of revenues, profits and employees. In an international study, van der Zwet $^{21}$ investigates the internationalisation of the 53 largest financial groups worldwide by looking at the geographical diversification of total revenues (gross written premiums). She finds that insurance groups are more internationally oriented than banking groups.

In sum, revenues (income), assets, employees and a count of foreign country activity are generally used to measure internationalisation for non-financial firms. For banks, the amount of foreign assets is the dominant indicator. ${ }^{15}$ For insurance companies, GWP is the dominant indicator for the measurement for internationalisation. ${ }^{6}$ Assets have become less meaningful as an indicator of internationalisation for insurance. Insurers are increasingly adopting a centralised asset management strategy by which they acquire assets globally, unrelated to the geographical spread of their insurance underwriting activities. Following Ramaswamy et $a l .{ }^{19}$ we use the dominant indicator to determine geographical segmentation in the insurance industry. This variable is the amount of GWP. If data on the geographical split of GWP is unavailable, we turn to a geographical split of employees and subsequently to the location of assets.

To analyse the geographic segmentation of European insurers, we denote the home country by $h$, all European countries by the set $E U$, and all countries outside the EU (the rest of the world) as the set $R O W$. The relative share of GWP of insurer $j$ in country $i$ is denoted by $\alpha_{i, j}$. The GWP of insurer $j$ in the home country, the rest of Europe and the rest of the world sum up to 1 , that is, we have that $\alpha_{h, j}+\alpha_{E U \backslash\{h\}, j}+\alpha_{R O W, j}=1$.

\footnotetext{
${ }^{16}$ For example, Geringer et al. (1989).

${ }^{17}$ Sullivan (1994).

${ }^{18}$ Gulamhussen et al. (2014).

${ }^{19}$ Ramaswamy et al. (1996).

${ }^{20}$ Eppink and van Rhijn (1988).

${ }^{21}$ van der Zwet (2003).
} 
At the country level, we can also split the origin of gross written premiums. $I C_{i, j}$ denotes the dummy for the domicile country of an insurance company (IC). The dummy $I C_{h, j}$ is 1 if insurer $j$ is domiciled in the home country, and 0 otherwise. Accordingly, $I C_{E U \backslash\{h\}, j}$ is 1 if insurer $j$ is domiciled in the rest of Europe and $I C_{R O W, j}$ is 1 if insurer $j$ is domiciled in the rest of the world. Formally, we calculate the following indices for the respective shares of country:

$$
\begin{gathered}
H_{i}=\frac{\sum_{j} a_{i, j} \cdot G W P_{j} \cdot I C_{h, j}}{\sum_{j} a_{i, j} \cdot G W P_{j}}, \\
R_{i}=\frac{\sum_{j} a_{i, j} \cdot G W P_{j} \cdot I C_{E U \backslash\{h\}, j}}{\sum_{j} a_{i, j} \cdot G W P_{j}}, \\
W_{i}=\frac{\sum_{j} a_{i, j} \cdot G W P_{j} \cdot I C_{R O W, j}}{\sum_{j} a_{i, j} \cdot G W P_{j}} .
\end{gathered}
$$

We denote the domestic share of country $i$ with $H_{i}$, the regional share with $R_{i}$ and the global share with $W_{i}$. Again, the domestic, regional and global GWP shares of country $i$ sum up to 1 . The GWP for each segment region is thus divided by the total premiums written by the insurer to determine the percentage GWP in each geographical segment. In some parts of the analysis region and world are separated, while in other parts they are added together under international INT. Throughout the paper, we use weighted averages (weighted by GWP) to establish the internationalisation of a group of countries (e.g. the EU) or a group of insurers (e.g. the top 20).

Following the trend of increased globalisation and consolidation in the insurance sector, we develop the hypothesis that the amount of cross-border GWP written in Europe has increased between 2000 and 2012. Specifically, we test that both the regional (H1) and the global (H2) share of GWP have increased during these years. By definition, this means that also the international GWP share must have increased (H3).

In order to test whether the international share of GWP of the European insurers has increased, and whether this trend is significant, we apply Tobit regression models. The Tobit regression model is used because our dependent variable, that is, the regional, global and international shares of the European insurers (denoted by $\alpha_{E U \backslash\{h\}}, \alpha_{R O W}$ and $\alpha_{I N T}$ ), is limited to values between zero and one. This could result in limitations when using an ordinary least squares regression (OLS) model. To test whether a trend exists we use the following regression equation:

$$
\begin{aligned}
\alpha_{i}(\text { Year }) & =\beta+\gamma(\text { Year }-1999)+\varepsilon_{i} \quad \text { with i } \epsilon\{E U \backslash\{h\}, \\
\text { for Years } & =2000,2001, \ldots 2012,
\end{aligned}
$$

where $\gamma$ indicates the trend coefficient.

Data

At the country level, comprehensive cross-border data is not available. The data sources on international insurance provide a scattered view of the European market. EIOPA publishes data on cross-border branches as a statistical annex to its Financial Stability Reports, while 
Table 1 Coverage of the available data in the EU (in $€ \mathrm{~m}$ )

\begin{tabular}{lcr}
\hline & 2011 & 2012 \\
\hline Total & & \\
Total GWP & $1,082,937$ & $1,115,583$ \\
& & \\
Cross-border & 346,631 & 365,411 \\
Cross-border GWP from sources & 387,548 & 402,020 \\
Total cross-border GWP & 89 & 91 \\
Coverage (in \%) & & \\
\hline
\end{tabular}

Sources: EIOPA statistical annex, OECD Insurance Statistics, Helsinki list, U.S. list.

Note: The percentage number displays the \% of total cross-border GWP written in the EU.

OECD Insurance Statistics provide an aggregate, albeit incomplete, overview of foreign subsidiaries. The EIOPA statistical annex contains insurance data, including country data on total country GWP, foreign branches and premiums of life and non-life insurance. Next, the OECD Insurance Statistics contain country data on the absolute number of foreign subsidiaries and GWP written by these subsidiaries and cover the majority of the large insurance markets in Europe, including Germany, Italy, the Netherlands and the U.K. However, for other larger countries such as France and Ireland, no data from the OECD are available. A complete picture of the European insurance market and its degree of internationalisation can therefore not be established from these sources.

This paper has circumvented the partial unavailability of these aggregate data by combining aggregate data with data from the so-called Helsinki list and the U.S. list. The Helsinki list is a bottom-up data set on all significant cross-border activities of European insurance groups that are active across borders in the EEA. EIOPA receives data from each group supervisor with a summary of cross-border activities such as the number of EU/EEA branches, EU/EEA subsidiaries, the number of branches/subsidiaries in non-EU/EEA countries and the GWP written by each insurance entity. All the major European crossborder insurers are included in this list, which makes the cross-border coverage very extensive. Nevertheless, the small, often more domestically oriented, insurers are not included. Finally, EIOPA provides the U.S. list of the subsidiaries and branches of insurers from the United States (U.S.) in the EEA. This U.S. list allows us to make the non-EU/EEA branch/subsidiary list as complete as possible. Schoenmaker and Sass ${ }^{22}$ provide a detailed description of the data and sources. Data from the Helsinki list and the U.S. list are confidential and can thus only be provided in aggregated form.

When combining these four sources (EIOPA statistical annex, OECD Insurance Statistics, Helsinki list and U.S. list), we cover around 90 per cent of all cross-border activities in the EU (see Table 1). We have thus data with which we can reliably estimate the degree of crossborder insurance activities in Europe.

At the firm level, we examine the consolidated balance sheets and income statements of insurers in Europe, North America and Asia. For Europe, we study the largest 25 insurers between 2000 and 2012. The top 25 insurers are selected on the basis of GWP. To make a

\footnotetext{
22 Schoenmaker and Sass (2014).
} 
comparison between Europe, North America and Asia, we study the largest 20 insurers between 2000 and 2012 from those continents. The geographic segmentation of insurers' GWP is collected from insurers' annual reports.

\section{Transforming the Helsinki list to country-level cross-border data}

In our research of internationalisation at the country level, we examine two aspects: (1) the number of cross-border subsidiaries and branches and (2) the total amount of premiums written in Europe by cross-border subsidiaries or branches. This section explains the methodology to transform the Helsinki list data into cross-border data at the country level.

National enterprises can be split into home enterprises and foreign-controlled enterprises (also called foreign subsidiaries). As branches are part of a parent company and thus do not have separate legal entity status, they fall outside this definition of enterprises. The starting point of our analysis is to use the number of national enterprises and cross-border branches from the EIOPA statistical annex. Next, to determine how many of the national enterprises are in foreign control, we combine data from the OECD Insurance Statistics and the Helsinki and U.S. lists. To resolve how many branches come from EU/EEA countries and how many from non-EU/EEA countries, we combine data from the EIOPA statistical annex with the Helsinki and U.S. lists.

To illustrate the above methodology, we take the case of Germany. In 2012, there are 387 national enterprises. The number of foreign-controlled insurance undertakings from the OECD Insurance Statistics is 50. However, with the detailed information from the Helsinki list, we obtain 53 foreign-controlled undertakings. This information is assumed to be more accurate and is thus used instead of the OECD Insurance Statistics. For branches, a similar methodology is performed. For instance, for Austria, the EIOPA statistical annex reports one non-EU/EEA branch in 2012, while we obtain one Swiss branch through the Helsinki list and four U.S. branches from the U.S. list. This adds up to five non-EU/EEA branches in 2012. Through this procedure of combining figures from the EIOPA statistical annex with figures from the Helsinki and U.S. lists for branches and figures from the OECD Insurance Statistics with figures from the Helsinki and U.S. lists for subsidiaries, we fill gaps in the data and thus improve reliability. In this procedure, we assume that data from EIOPA's statistical annex and the OECD Insurance Statistics to be correct unless calculations with more detailed information lead to a higher number of foreign branches or subsidiaries.

Research on the (cross-border) GWP in Europe is more challenging. Figure 1 illustrates how we determine country GWP per company type (national, home and foreign-controlled enterprises and foreign branches). For those countries for which OECD Insurance Statistics are available, we use data on GWP written by foreign-controlled enterprises and combine these with more detailed information from the Helsinki and U.S. lists. Countries without OECD data are solely covered by the Helsinki and U.S. lists. From the EIOPA statistical annex, we take the total amount of GWP written by national enterprises and the amount written by EU/EEA and non-EU/EEA branches. Finally, to determine the GWP written by home enterprises, we subtract the GWP written by foreign-controlled enterprises, including the estimated amounts explained in the next paragraph, from the GWP written by national enterprises.

Having deduced GWP figures on foreign branches and subsidiaries with available data, we still need to go from around 90 per cent (see Table 1) to 100 per cent of the cross-border 


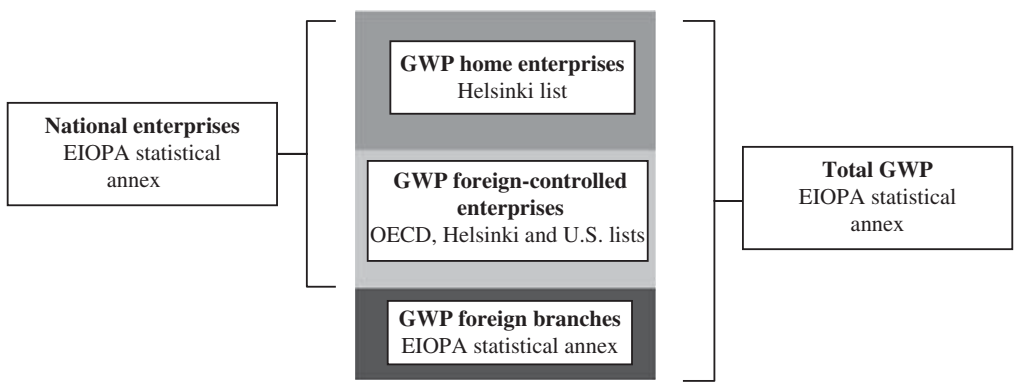

Figure 1. Transforming insurance statistics into domestic and cross-border data. Note: The data variables are illustrated in bold and the sources in normal letters.
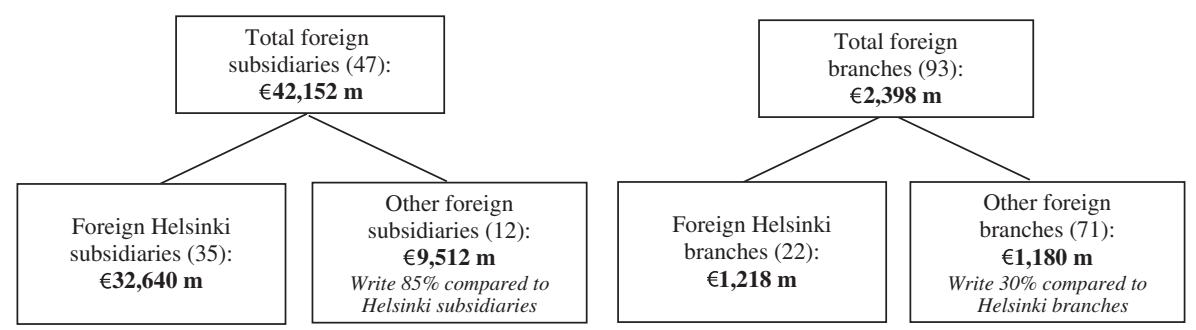

Figure 2. Overview for France.

Note: GWP for "other" foreign subsidiaries or branches is estimated.

Source: EIOPA statistical annex, OECD Insurance Statistics, Helsinki list, U.S. list; authors' calculations.

market in the EU. In order to do this, we make certain approximations and assumptions to determine the remaining 10 per cent. For the countries for which subsidiaries are not covered by OECD Insurance Statistics and/or branches not covered by EIOPA statistical annex data, we do know the number of subsidiaries and branches for which GWP is disclosed by the Helsinki and U.S. lists as well as the number of subsidiaries and branches for which GWP is not disclosed. In order to determine GWP for these still uncovered entities, we need to make assumptions. Examining the OECD Insurance Statistics more closely, we find that enterprises that are not on the Helsinki list write about 85 per cent as much GWP as enterprises on the Helsinki list. For branches, we find that branches not on the Helsinki list write around 30 per cent as much GWP as branches on the Helsinki list. Figures below 100 per cent are to be expected, as the Helsinki list covers the material entities. With these assumptions, we calculate the GWP that is written by the remaining insurance entities. After adding these figures to the existing cross-border GWP, the remainder of the GWP must be written by home enterprises, as all foreign subsidiaries and branches are now covered. This leads to a complete picture of the insurance market in Europe. It appears that only around 3-4 per cent of total GWP in Europe has to be estimated (see Schoenmaker and Sass ${ }^{23}$ for the full details).

To get a full picture of our methodology, Figure 2 illustrates the case for France in 2012. The EIOPA statistical annex shows that GWP in France written by national enterprises is $€ 200$ bn and GWP written by non-EU/EEA branches is €0.1bn. Information on EU/EEA 
branches is not available. By adding up the information from the Helsinki and U.S. lists, we obtain GWP from 163 domestic insurers of $€ 140 \mathrm{bn}$, GWP from 35 foreign subsidiaries of $€ 33 \mathrm{bn}$, GWP from 20 EU branches of $€ 0.8 \mathrm{bn}$ and GWP from 2 non-EU branches of $€ 0.4 \mathrm{bn}$. The information so far is already more detailed than the EIOPA statistical annex. However, comparing these figures to our established total number of branches and subsidiaries, 47 and 93 respectively, we find that we need to approximate GWP for 12 foreign subsidiaries, $61 \mathrm{EU} / \mathrm{EEA}$ branches and 10 non-EU/EEA branches, as these are not in the Helsinki and U.S. lists. With the assumption that these subsidiaries write 85 per cent as much as subsidiaries from the Helsinki list and the branches write 30 per cent as much as branches from the Helsinki list, Figure 2 provides cross-border insurance data for France. Illustration: Other foreign subsidiaries write 85 per cent of Helsinki list subsidiaries, so not $€ 32,640 \mathrm{~m}$ divided by 35 per entity but $€ 32,640 \mathrm{~m}$ divided by 35 times 85 per cent.

The next step is to split the GWP that is approximated for some foreign subsidiaries and foreign branches into GWP from EU/EEA and non-EU/EEA. Table 3 shows that, in the European Economic Area, about 80 per cent of the branches is from the EU/EEA and 20 per cent from non-EU/EEA countries. We thus assume that about 80 per cent of the GWP that is approximated is written by EU/EEA enterprises and 20 per cent by non-EU/EEA enterprises. The overview for France at this stage is presented in Table 2.

Finally, in order to compare the results with the results found for the banking sector, we need to obtain the amounts written by EU subsidiaries and EU branches. We thus need to filter GWP from EEA countries that are not in the EU (i.e. Iceland, Liechtenstein and Norway). We start this filtering with the GWP amounts written by EEA insurers from the Helsinki list. These are only two insurers: Storebrand and Gjensidige ASA from Norway. Secondly, we need to adjust our previously calculated ratio of 80:20 that was used to approximate the GWP of EU/EEA to non-EU/EEA enterprises. Table 3 indicates that about 2 per cent of the total GWP is written in EEA countries. Therefore, we adjust our ratio to 78:22 EU to non-EU, as the EEA share is added to the third country share.

\section{Cross-border insurance in Europe}

In this section we present the findings on cross-border insurance activity in Europe. Table 3 first shows the size of the insurance market in every European country in

Table 2 Overview for France

\begin{tabular}{lr}
\hline France & $G W P(€ m)$ \\
\hline National enterprises & 200,337 \\
$\quad$ of which EU/EEA subsidiaries & 36,360 \\
$\quad$ of which non-EU/EEA subsidiaries & 5,792 \\
EU/EEA branches & 1,853 \\
Non-EU/EEA branches & 545 \\
Total & 202,735 \\
\hline
\end{tabular}

Note: Aggregated non-EU/EEA Helsinki GWP for foreign subsidiaries amounts to $€ 3,698 \mathrm{~m}$. For branches it adds up to $€ 379 \mathrm{~m}$. 
Table 3 European insurance market overview (2012)

\begin{tabular}{|c|c|c|c|c|c|c|}
\hline & $\begin{array}{c}\text { Euro }(€) \text {, } \\
\text { millions }\end{array}$ & $\begin{array}{c}\% \text { of } \\
G D P(\%)\end{array}$ & $\begin{array}{c}\text { Home } \\
\text { enterprises }\end{array}$ & $\begin{array}{c}\text { Foreign-controlled } \\
\text { enterprises }\end{array}$ & $\begin{array}{l}\text { EU/EEA } \\
\text { branches }\end{array}$ & $\begin{array}{c}\text { Non-EU/EEA } \\
\text { branches }\end{array}$ \\
\hline Austria & 17,697 & 6 & 27 & 20 & 28 & 5 \\
\hline Belgium & 32,388 & 9 & 53 & 37 & 46 & 5 \\
\hline Bulgaria & 901 & 2 & 10 & 24 & 10 & 0 \\
\hline Croatia & 1,244 & 3 & na & na & na & na \\
\hline Cyprus & 846 & 5 & 19 & 8 & 5 & 1 \\
\hline Czech Republic & 6,433 & 4 & 11 & 24 & 18 & 2 \\
\hline Denmark & 25,485 & 10 & 119 & 13 & 44 & 8 \\
\hline Estonia & 300 & 2 & 3 & 9 & 5 & 0 \\
\hline Finland & 8,546 & 4 & 50 & 4 & 20 & 5 \\
\hline France & 202,735 & 10 & 287 & 47 & 80 & 13 \\
\hline Germany & 192,530 & 7 & 334 & 53 & 78 & 15 \\
\hline Greece & 4,829 & 2 & 35 & 18 & 19 & 3 \\
\hline Hungary & 2,824 & 3 & 9 & 26 & 15 & 1 \\
\hline Iceland & 435 & 4 & 11 & 2 & 1 & 0 \\
\hline Ireland & 35,174 & 21 & 66 & 179 & 33 & 11 \\
\hline Italy & 116,933 & 7 & 77 & 58 & 98 & 21 \\
\hline Latvia & 304 & 1 & 4 & 5 & 13 & 0 \\
\hline Liechtenstein & 3,620 & 85 & 17 & 23 & 1 & 17 \\
\hline Lithuania & 518 & 2 & 3 & 8 & 14 & 0 \\
\hline Luxembourg & 23,285 & 54 & 27 & 285 & 15 & 0 \\
\hline Malta & 306 & 4 & 25 & 33 & 7 & 1 \\
\hline Netherlands & 79,009 & 13 & 190 & 22 & 73 & 12 \\
\hline Norway & 20,805 & 5 & 71 & 3 & 34 & 6 \\
\hline Poland & 15,615 & 4 & 14 & 45 & 18 & 5 \\
\hline Portugal & 8,471 & 5 & 23 & 19 & 36 & 8 \\
\hline Romania & 1,935 & 1 & 24 & 17 & 10 & 1 \\
\hline Slovakia & 2,283 & 3 & 2 & 16 & 19 & 2 \\
\hline Slovenia & 2,002 & 6 & 14 & 4 & 5 & 0 \\
\hline Spain & 62,166 & 6 & 211 & 59 & 79 & 19 \\
\hline Sweden & 18,651 & 5 & 117 & 55 & 37 & 12 \\
\hline United Kingdom & 252,173 & 13 & 210 & 156 & 61 & 17 \\
\hline EU/EEA & $1,140,443$ & 8.6 & 2,063 & 1,272 & 922 & 190 \\
\hline EU & $1,115,583$ & 8.5 & 1,964 & 1,244 & 886 & 167 \\
\hline
\end{tabular}

Sources: EIOPA statistical annex, OECD Insurance Statistics, Helsinki list, U.S. list, Eurostat; authors' calculations. Note: na is not available. Enterprises and Branches are in numbers.

absolute terms and in terms of gross domestic product (GDP). The insurance industry in France, Germany, Italy, the Netherlands, Spain and the United Kingdom (U.K.) are the largest in Europe in absolute terms. Combined they represent 81 per cent of all the insurance premiums written in the EU. In terms of relative size, countries such as Ireland, Liechtenstein and Luxembourg score extremely high, with written premiums being 21, 85 and 54 per cent of GDP. Legal and tax benefits, such as a 12.5 per cent corporate tax rate in Ireland, can encourage insurers to locate insurance entities in such a country. 


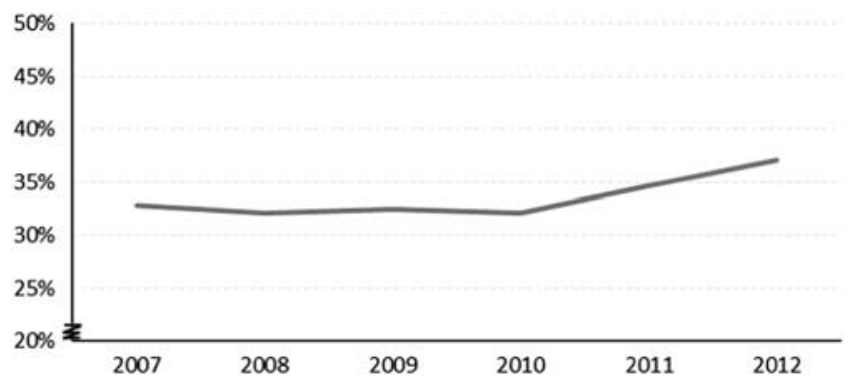

Figure 3. Number of foreign-controlled subsidiaries as percentage of national enterprises. Note: National enterprises are split into foreign-controlled subsidiaries and home enterprises. Source: EIOPA statistical annex, OECD Insurance Statistics, Helsinki list, U.S. list; authors' calculations.

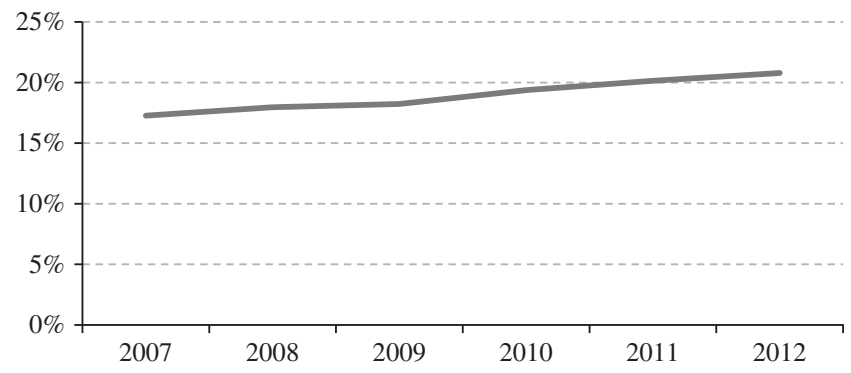

Figure 4. Total insurance activity by number of branches in the EU (as a per cent). Note: Foreign branches as percentage of total number of national enterprises and foreign branches. Source: EIOPA statistical annex, OECD Insurance Statistics, Helsinki list, U.S. list; authors' calculations.

Starting with subsidiaries, Figure 3 indicates that the number of foreign subsidiaries as a percentage of national enterprises is slightly increasing. While, in 2007, 33 per cent of all national enterprises in a country were controlled by foreign parents, this percentage increased to 37 per cent in 2012. Another option for an insurer is to obtain presence in a country through branches. The main difference has a legal character, as subsidiaries are separate entities in the foreign country whereas branches are not. The number of foreign branches as a percentage of national enterprises and foreign branches also increased from 17 per cent in 2007 to 21 per cent in 2012 (Figure 4). Finally, Table 3 shows the number of foreign subsidiaries and branches at country level in Europe. It is remarkable that Ireland and Luxembourg have far more foreign-controlled insurers than domestic insurers.

In addition to writing insurance premiums in foreign countries through subsidiaries or branches, international activity under the Freedom to Provide Services (FPS) is a third way to enter a foreign market. An insurer that uses the Internet or other communication tools to sell insurance in foreign markets is allowed to do so as part of the European Single Market. Supervisors and EIOPA have started to capture FPS of national enterprises, but do not specify the location of these premiums. Schoenmaker and Sass ${ }^{22}$ show that premiums through FPS would only add up to about 3 per cent of total GWP in 2012. We thus do not 
Table 4 Foreign penetration of the European insurance market (2012)

\begin{tabular}{|c|c|c|c|c|}
\hline \multirow{2}{*}{ Countries } & \multicolumn{3}{|c|}{ Share in GWP } & \multirow[b]{2}{*}{ International (\%) } \\
\hline & Domestic (\%) & Regional (\%) & Global (\%) & \\
\hline Austria & 66 & 29 & 5 & 34 \\
\hline Belgium & 47 & 46 & 7 & 53 \\
\hline Bulgaria & 36 & 63 & 0 & 64 \\
\hline Croatia & 56 & 39 & 5 & 44 \\
\hline Cyprus & 29 & 53 & 18 & 71 \\
\hline Czech Republic & 1 & 98 & 1 & 99 \\
\hline Denmark & 69 & 28 & 3 & 31 \\
\hline Estonia & 3 & 96 & 1 & 97 \\
\hline Finland & 62 & 37 & 1 & 38 \\
\hline France & 78 & 19 & 3 & 22 \\
\hline Germany & 75 & 18 & 7 & 25 \\
\hline Greece & 46 & 52 & 2 & 54 \\
\hline Hungary & 6 & 92 & 2 & 94 \\
\hline Iceland & 87 & 13 & 0 & 13 \\
\hline Ireland & 4 & 61 & 35 & 96 \\
\hline Italy & 66 & 29 & 5 & 34 \\
\hline Latvia & 23 & 58 & 20 & 77 \\
\hline Liechtenstein & 16 & 47 & 38 & 84 \\
\hline Lithuania & 23 & 74 & 3 & 77 \\
\hline Luxembourg & 16 & 68 & 16 & 84 \\
\hline Malta & 38 & 44 & 18 & 62 \\
\hline Netherlands & 83 & 14 & 2 & 17 \\
\hline Norway & 73 & 26 & 0 & 27 \\
\hline Poland & 35 & 63 & 2 & 65 \\
\hline Portugal & 39 & 50 & 10 & 61 \\
\hline Romania & 24 & 73 & 3 & 76 \\
\hline Slovakia & 8 & 90 & 3 & 92 \\
\hline Slovenia & 88 & 12 & 0 & 12 \\
\hline Spain & 68 & 26 & 6 & 32 \\
\hline Sweden & 48 & 38 & 13 & 52 \\
\hline United Kingdom & 58 & 32 & 10 & 42 \\
\hline Euro area & 68 & 26 & 6 & 32 \\
\hline Non-euro area & 55 & 36 & 9 & 45 \\
\hline EU & 64 & 29 & 7 & 36 \\
\hline EU/EEA & 64 & 29 & 7 & 36 \\
\hline
\end{tabular}

Source: EIOPA statistical annex, OECD Insurance Statistics, Helsinki list, U.S. list; authors' calculations.

Note: Numbers are a percentage of total country GWP. Regional $\left(R_{i}\right)$ is rest of EU, global $\left(G_{i}\right)$ is non-EU, international $\left(I N T_{i}\right)$ is regional and global combined. Owing to rounding, figures do not always exactly add up to 100. Weighted averages (weighted by GWP) are used for euro area/EU aggregates.

include FPS figures in our research, which implies that we are slightly understating crossborder insurance.

Table 4 provides the geographic segmentation of GWP at country level. Using Eqs 1-3, $H_{i}$ (domestic share), $R_{i}$ (regional share) and $G_{i}$ (global share) are reported. The average of $R_{i}$ is 29 per cent for the EU, while the average of $G_{i}$ is 7 per cent (all weighted by GWP). 


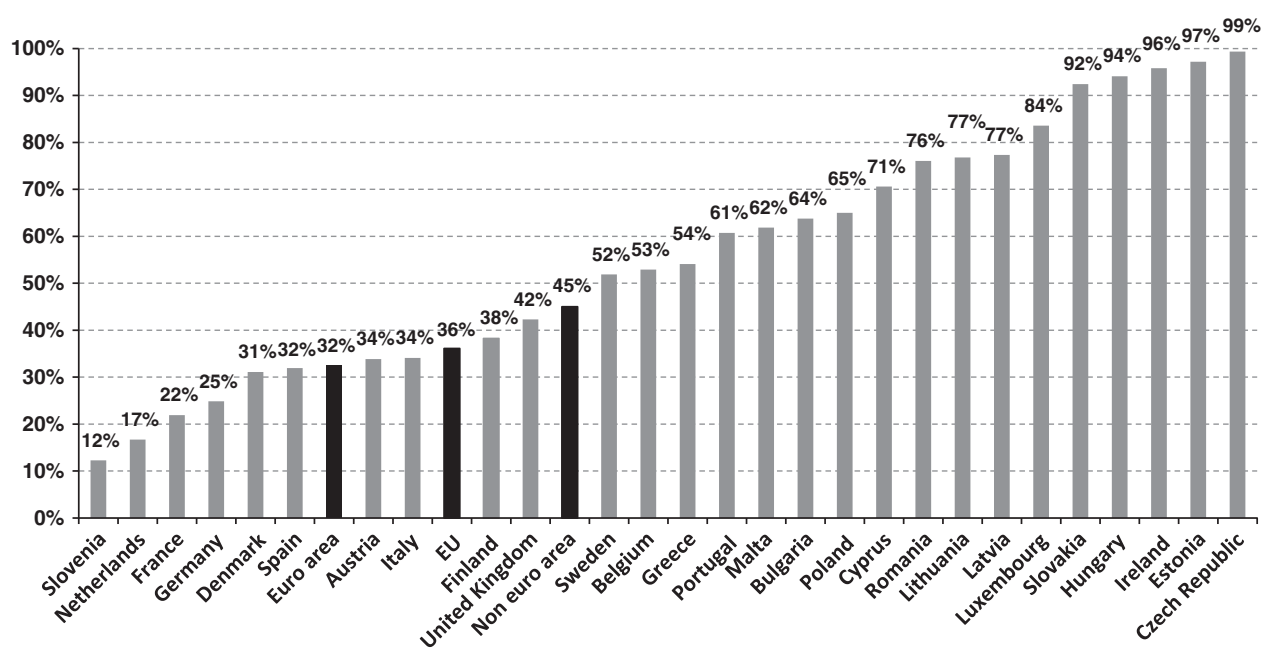

Figure 5. Degree of foreign penetration of European insurance markets (per cent of total GWP).

Note: GWP from foreign subsidiaries and foreign branches is added together and divided by total GWP in order to arrive at the degree of foreign penetration for each country.

Source: Table 4.

That adds up to a total of 36 per cent cross-border insurance. Some of the new Member States, such as the Czech Republic, Estonia, Hungary, and Slovakia, have very low $H_{i}$ and are thus very internationally oriented with more than 80 per cent of GWP written by foreign entities. This is also the case for Ireland, Liechtenstein and Luxembourg. These latter countries (as well as Cyprus and Malta) also have a relatively large $G_{i}$, indicating that they are countries of choice for insurers outside Europe. Figure 5 ranks the EU countries by degree of foreign penetration. Our findings are in line with research from the European Commission Expert Group. ${ }^{23}$

Table 5 presents a further breakdown of the overall result of 36 per cent cross-border insurance in the EU. First, it appears that around 29 per cent of the GWP is written by subsidiaries or branches from other EU countries, while 7 per cent is written by foreign subsidiaries or branches from non-EU countries. Table 5, which summarises the means through which cross-border premiums are written, illustrates that most of the cross-border GWP is written through subsidiaries and not through branches. In the EU, around 31 per cent of the cross-border GWP is written through subsidiaries and only 5 per cent through branches. See Figure 6 for a graphical representation of results. Branches thus turn out to be a less attractive way for an insurer to write cross-border premiums. Though in some countries such as Latvia, Lithuania and Portugal, the GWP amount written through foreign branches is relatively high.

With respect to the difference between euro area and non-euro area countries, there is some difference in internationalisation between these countries. Tables 4 and 5 indicate that

\footnotetext{
${ }^{23}$ European Commission (2014).
} 
Table 5 Foreign penetration through branches and subsidiaries in Europe (2012)

\begin{tabular}{|c|c|c|c|c|c|}
\hline Countries & $\begin{array}{c}\text { Branches from } \\
\text { EU }(\%)\end{array}$ & $\begin{array}{c}\text { Subsidiaries from } \\
E U(\%)\end{array}$ & $\begin{array}{c}\text { Branches from } \\
\text { non } E U(\%)\end{array}$ & $\begin{array}{c}\text { Subsidiaries from } \\
\text { non EU (\%) }\end{array}$ & $\begin{array}{l}\text { Total cross- } \\
\text { border (\%) }\end{array}$ \\
\hline Austria & 1.8 & 27.3 & 0.1 & 4.6 & 33.8 \\
\hline Belgium & 2.9 & 43.4 & 0.6 & 6.0 & 52.9 \\
\hline Bulgaria & 9.3 & 54.1 & 0.0 & 0.4 & 63.8 \\
\hline Croatia & 3.7 & 35.4 & 0.0 & 4.8 & 43.9 \\
\hline Cyprus & 8.2 & 44.5 & 4.6 & 13.3 & 70.6 \\
\hline Czech Republic & 9.6 & 88.6 & 0.4 & 0.8 & 99.3 \\
\hline Denmark & 4.5 & 23.9 & 0.3 & 2.3 & 31.1 \\
\hline Estonia & 17.0 & 78.7 & 0.0 & 1.5 & 97.2 \\
\hline Finland & 8.5 & 28.8 & 1.0 & 0.0 & 38.3 \\
\hline France & 0.8 & 18.0 & 0.3 & 2.9 & 21.9 \\
\hline Germany & 3.1 & 15.0 & 2.4 & 4.4 & 24.9 \\
\hline Greece & 11.1 & 41.4 & 0.1 & 1.5 & 54.1 \\
\hline Hungary & 6.2 & 86.2 & 0.8 & 0.9 & 94.1 \\
\hline Iceland & 4.8 & 8.6 & 0.0 & 0.0 & 13.4 \\
\hline Ireland & 5.2 & 56.0 & 1.7 & 32.9 & 95.8 \\
\hline Italy & 6.0 & 23.3 & 3.2 & 1.6 & 34.1 \\
\hline Latvia & 30.6 & 27.1 & 0.0 & 19.6 & 77.3 \\
\hline Liechtenstein & 5.6 & 41.2 & 5.6 & 32.2 & 84.5 \\
\hline Lithuania & 40.3 & 33.8 & 0.0 & 2.6 & 76.8 \\
\hline Luxembourg & 0.5 & 67.5 & 0.0 & 15.5 & 83.6 \\
\hline Malta & 10.0 & 33.6 & 1.5 & 16.8 & 61.8 \\
\hline Netherlands & 4.2 & 10.1 & 0.8 & 1.6 & 16.7 \\
\hline Norway & 19.2 & 6.9 & 0.4 & 0.0 & 26.6 \\
\hline Poland & 3.6 & 59.5 & 0.8 & 1.1 & 65.0 \\
\hline Portugal & 21.3 & 28.9 & 9.9 & 0.6 & 60.7 \\
\hline Romania & 5.0 & 68.5 & 2.6 & 0.0 & 76.1 \\
\hline Slovakia & 9.9 & 79.9 & 0.9 & 1.7 & 92.4 \\
\hline Slovenia & 4.0 & 8.3 & 0.0 & 0.0 & 12.3 \\
\hline Spain & 4.2 & 21.9 & 3.1 & 2.8 & 31.9 \\
\hline Sweden & 7.9 & 30.5 & 2.9 & 10.6 & 51.9 \\
\hline United Kingdom & 3.0 & 29.5 & 1.9 & 7.9 & 42.3 \\
\hline Euro area & 3.5 & 22.5 & 1.7 & 4.7 & 32.4 \\
\hline Non-euro area & 3.7 & 32.5 & 1.7 & 7.0 & 45.0 \\
\hline EU & 3.5 & 25.5 & 1.7 & 5.4 & 36.1 \\
\hline EU/EEA & 3.8 & 25.2 & 1.7 & 5.4 & 36.1 \\
\hline
\end{tabular}

Source: Table 4.

Note: Regional and global shares from Table 4 are each split into branches and subsidiaries. The last column adds columns 2-5. Weighted averages (weighted by GWP) are used for (non)-euro area, EU/EEA.

about 45 per cent of GWP in non-euro area countries was written by foreign entities, while this was only 32 per cent in euro area countries. In order to understand this, we look at the largest insurance companies from Europe in Table 8. These large insurers are clearly coming from the larger countries. For the euro area, these countries are Germany, France, Italy, Spain and the Netherlands and for the non-euro area, the U.K. and Sweden. In Table 8, we find that insurers from non-euro area countries are very internationally oriented. U.K. insurers, in particular, are very internationally focused. Prudential obtains 77 per cent of its GWP from 


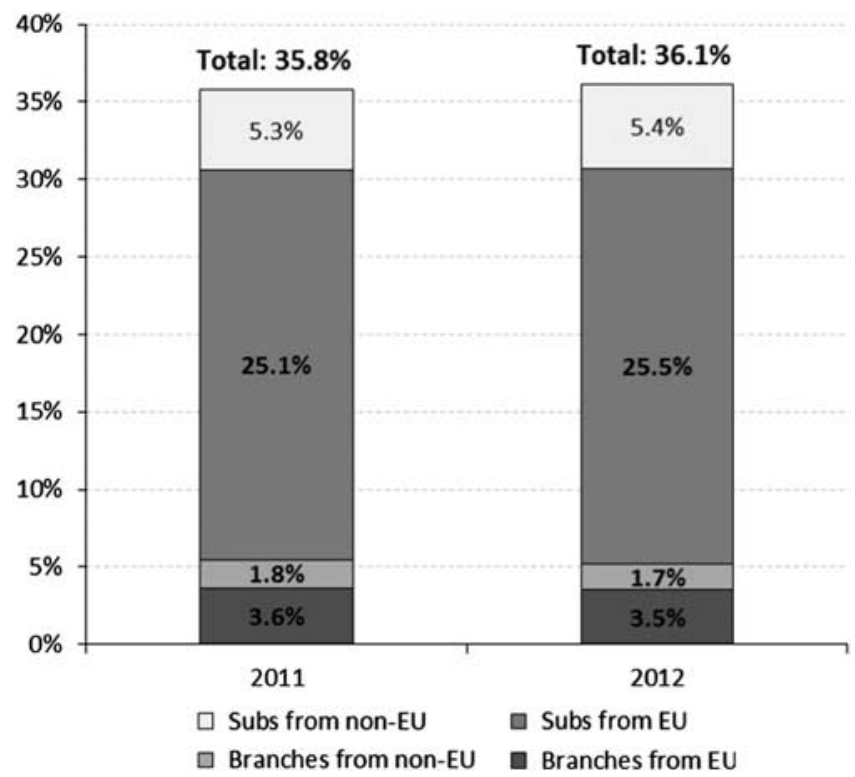

Figure 6. Insurance: Origin of cross-border activity.

Note: This graph represents the origin of cross-border GWP as a percentage of total GWP and makes a split in EU/ non-EU branches and subsidiaries. The percentage represents the share of GWP that comes from abroad. Source: Table 5.

abroad and RSA 64 per cent. This could explain the high degree of internationalisation in non-euro area countries.

Finally, it would be interesting to examine the difference in foreign penetration with the banking system. As discussed in the previous section, total foreign assets are the dominant indicator to measure the degree of internationalisation for banks. Applying a comparable methodology based on TNI (see the section "Methodology") to collect cross-border data on banking, Schoenmaker ${ }^{15}$ reports a figure of 25 per cent for cross-border banking in the EU. The degree of foreign penetration is lower than in the insurance market, with "only" about 25 per cent of banking activity coming from foreign players compared with 36 per cent in the insurance market (Figure 7). This is in line with the findings of van der Zwet ${ }^{21}$ and Focarelli and Pozzolo, ${ }^{24}$ which also find that the insurance sector is more internationally oriented than the banking sector.

\section{Internationalisation of large insurance companies}

Having found a high degree of internationalisation from a country perspective, we now turn to internationalisation of insurance groups from a firm perspective. This section looks at the largest insurers from Europe and their international activities measured by GWP. This

\footnotetext{
${ }^{24}$ Focarelli and Pozzolo (2008).
} 


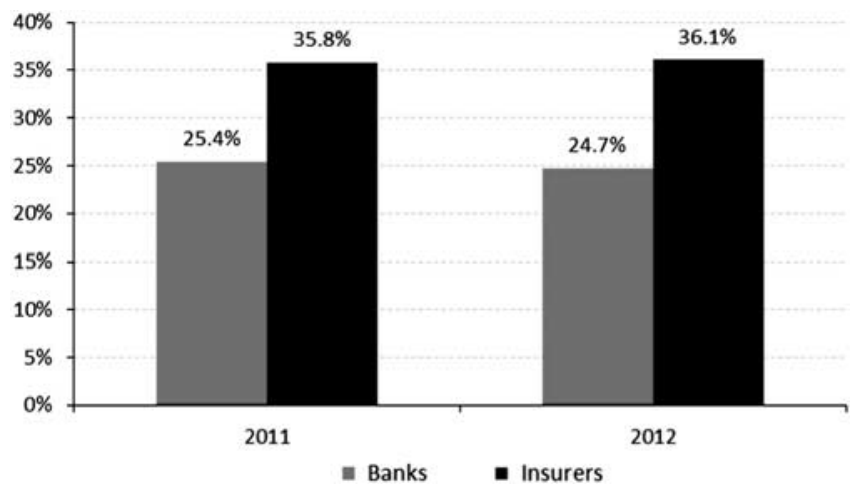

Figure 7. Cross-border state of banks and insurers in EU countries.

Note: This graph represents the degree of foreign penetration in countries from the EU for both banking and insurance. The percentage represents the share of GWP that comes from abroad.

Source: Schoenmaker (2013) for banking and Table 5 for insurance.

section also makes a comparison between the largest insurers from Europe, North America and Asia. Finally, we test whether the international share of GWP of insurers has increased.

\section{Internationalisation of the largest European insurers}

We start with constructing an overview of the largest insurers from Europe and their degree of internationalisation. As the paper aims to identify the scope for supervisory coordination problems due to internationalisation, the large insurers are grouped according to the degree of internationalisation in relative terms. Following Schoenmaker et al. ${ }^{25}$ we classify insurers $j$ into "domestic", "semi-international", "regional" and "global". An insurer is "domestic" if 75 per cent or more of the premiums are written in the home country: $\alpha_{h, j} \geqslant 0.75$. A "semiinternational" insurer writes between 50 and 75 per cent of its premiums in the home country: $0.5 \leqslant \alpha_{h, j}<0.75$. A "regional" insurer writes less than 50 per cent of its premiums in the home country and a majority of the remaining international premiums in the rest of Europe: $\alpha_{h, j}<0.5$ and $\alpha_{E U \backslash\{h\}, j}>\alpha_{R O W, j}$. Finally, a "global" insurer also writes less than 50 per cent in the home country, but the majority of its international premiums in the rest of the world: $\alpha_{h, j}<0.5$ and $\alpha_{R O W, j}>\alpha_{E U \backslash h\}, j}$. Table 6 presents an overview of the largest 25 European insurers and their classification. It appears that 15 out of the 25 of the large European insurers are very internationally oriented, with nine European insurers classified as "global" and six as "regional". Furthermore, insurers from the Netherlands and the U.K. are more internationally oriented than insurers from France, which has more domestic insurers such as CNP, Covéa and Groupama. The 25 largest insurers wrote on average 42 per cent of GWP in the home country $\left(\alpha_{h}=0.42\right), 32$ per cent in the region $\left(\alpha_{E U \backslash\{h\}}=0.32\right)$ and 26 per cent in the rest of the world $\left(\alpha_{R O W}=0.26\right)$ in 2012.

\footnotetext{
${ }^{25}$ Schoenmaker et al. (2008).
} 
Table 6 Classification of the largest European insurance groups (2012)

\begin{tabular}{|c|c|c|c|c|c|c|}
\hline Insurance groups & Country & $G W P(€ m)$ & Total assets $(€ m)$ & $H(\%)$ & $R(\%)$ & $W(\%)$ \\
\hline \multicolumn{7}{|l|}{ Global } \\
\hline Zurich Financial Services & $\mathrm{CH}$ & 38,843 & 309,980 & 11 & 40 & 49 \\
\hline Prudential & U.K. & 36,812 & 380,165 & 23 & 0 & 77 \\
\hline Talanx & $\mathrm{DE}$ & 26,659 & 130,254 & 35 & 32 & 33 \\
\hline MAPFRE & ES & 21,579 & 56,983 & 37 & 7 & 56 \\
\hline ING Group & NL & 20,277 & 339,513 & 36 & 23 & 41 \\
\hline AEGON & NL & 19,526 & 366,118 & 19 & 35 & 46 \\
\hline $\mathrm{ACE}$ & $\mathrm{CH}$ & 21,593 & 70,094 & 18 & 0 & 82 \\
\hline Royal \& Sun Alliance [RSA] & U.K. & 11,566 & 28,043 & 36 & 30 & 34 \\
\hline SCOR & FR & 9,514 & 32,590 & 22 & 20 & 58 \\
\hline \multicolumn{7}{|l|}{ Regional } \\
\hline AXA & FR & 84,592 & 761,849 & 23 & 50 & 27 \\
\hline Allianz & $\mathrm{DE}$ & 72,086 & 694,621 & 25 & 44 & 31 \\
\hline Generali & IT & 69,613 & 441,745 & 29 & 65 & 6 \\
\hline BNP Paribas & FR & 19,813 & 170,000 & 32 & 45 & 23 \\
\hline Swiss Life & $\mathrm{CH}$ & 9,978 & 125,787 & 49 & 47 & 4 \\
\hline Vienna Insurance Group & AT & 9,686 & 42,336 & 43 & 57 & 0 \\
\hline \multicolumn{7}{|l|}{ Semi-international } \\
\hline Aviva & U.K. & 27,993 & 388,540 & 50 & 34 & 16 \\
\hline Credit Agricole & FR & 22,914 & 291,100 & 66 & 30 & 4 \\
\hline Ageas & $\mathrm{BE}$ & 9,947 & 97,113 & 64 & 33 & 3 \\
\hline \multicolumn{7}{|l|}{ Domestic } \\
\hline Lloyds & U.K. & 31,385 & 80,736 & 82 & 5 & 13 \\
\hline $\mathrm{CNP}$ & FR & 26,439 & 353,216 & 81 & 8 & 11 \\
\hline Achmea & NL & 20,455 & 94,817 & 94 & 6 & 0 \\
\hline ERGO & $\mathrm{DE}$ & 17,091 & 147,208 & 77 & 18 & 5 \\
\hline Covéa & FR & 14,815 & 87,334 & 89 & 10 & 1 \\
\hline Groupama & FR & 10,764 & 87,946 & 80 & 20 & 0 \\
\hline Unipol Gruppo Finanziario & IT & 11,925 & 83,109 & 100 & 0 & 0 \\
\hline Top 25 insurance groups & - & 26,635 & 226,448 & 42 & 32 & 26 \\
\hline
\end{tabular}

Source: Authors' calculations based on annual reports.

Note: GWP and total assets are in $€ \mathrm{~m}$. This table classifies the largest 25 European insurance groups into global, regional, semi-international and domestic groups. Purpose of this table is to show insurers' geographical focus in relative GWP terms. An insurer is global if it has more than 50 per cent of its premiums from abroad with a majority of the foreign premiums from the rest of the world (W). If it has more in the rest of the region $(R)$ category it is classified as regional. If an insurer has 50-75 per cent of its revenue from the home country $(H)$, it is semiinternational. An insurer is domestic if it obtains more than 75 per cent of its GWP from the home market. In the bottom row the weighted average is presented (internationalisation weighted by GWP).

To examine the evolution of internationalisation, Schoenmaker and Sass ${ }^{22}$ provide a detailed overview of the biggest insurers and their GWP segmentation from 2000 to 2012. There are entries and exits of insurers in the top 25 due to increases and decreases of GWP of particular insurers. The largest insurers such as AXA, Allianz, Aviva and Generali obtain most of their business from abroad throughout the 2000-2012 period. It also appears that 


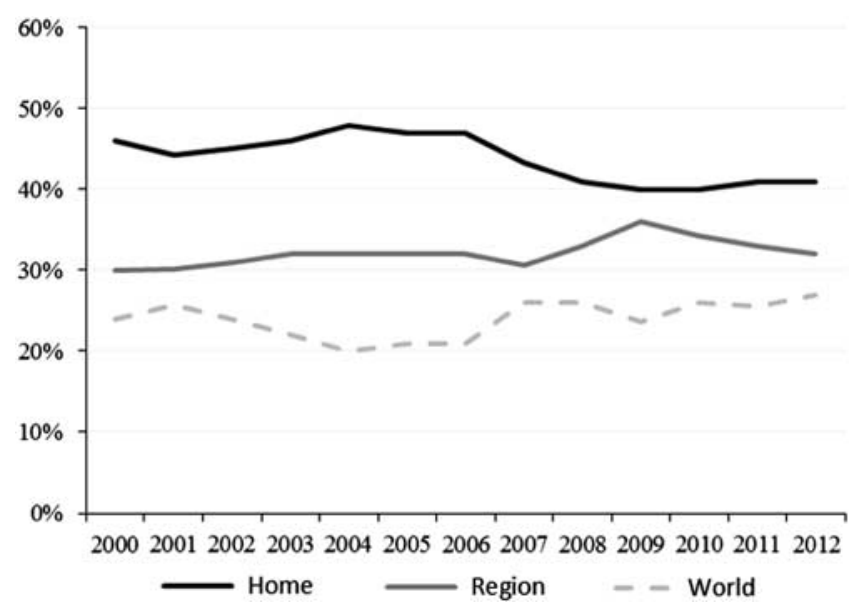

Figure 8. Geographical segmentation of top 25 insurers in Europe.

Note: This figure shows the geographical segmentation of the 25 biggest European insurance companies for the years 2000-2012. The segmentation is established by assigning the GWP per insurer to the classes home (domestic), region (rest of Europe) and world (non-Europe). Calculations are made on a weighted average basis.

Source: Authors' calculations.

they have increased in size much faster than their competitors. In particular, AXA, Allianz and Generali have grown substantially over the 2000-2012 period, while Aviva has decreased in size through the divestment of its Dutch subsidiary, Delta Lloyd, in 2009.

Figure 8 shows a graphical representation of GWP from the home country, the region and the world from 2000 to 2012. The percentage of GWP that is written in the home country has decreased since 2000, although a slight increase can be identified between 2001 and 2004 . The percentage of GWP that is written at home has reduced from 46 per cent in 2000 to only 42 per cent in 2012. Accordingly, the percentage of international GWP has increased from 54 per cent of GWP in 2000 (30 per cent from region and 24 per cent from world) to 58 per cent in 2012 (32 per cent from region and 26 per cent from world).

Next, it appears that the geographical share of world is increasing over the last few years and "catching up" with the premiums share from the region. Figure 8 illustrates that the share of world has increased from 24 per cent in 2009 to around 26 per cent in 2012 . In contrast, the share of region has decreased from 35 per cent in 2009 to 32 per cent in 2012. Prudential, ACE, Allianz have all seen a decrease in the relative importance of regional GWP, while these insurers as well as Zurich Financial Services and MAPFRE have greatly increased their presence in countries outside of Europe.

\section{Comparison between regions}

Following the same methodology, we now look at the difference in the degree of internationalisation between the largest insurers from Europe, Asia and North America. Schoenmaker and $\mathrm{Sass}^{22}$ report detailed figures for Asia and North America. Insurers from Asia are generally active in Japan, India, China, South East Asia and Oceania, but very few 
Table 7 Degree of internationalisation of the largest insurers across continents

\begin{tabular}{llcccc}
\hline Continent & Segment & $2000(\%)$ & $2004(\%)$ & $2008(\%)$ & $2012(\%)$ \\
\hline North America & Home & 80 & 76 & 74 & 78 \\
& Region & 5 & 13 & 11 & 3 \\
& World & 15 & 11 & 15 & 19 \\
Asia & & & 97 & 95 & 96 \\
& Home & - & 1 & 2 & 2 \\
& Region & - & 2 & 3 & 2 \\
Europe & World & - & 45 & 40 & 40 \\
& Home & 48 & 34 & 21 & 33 \\
& Region & 30 & 22 & 27 & 27 \\
\hline
\end{tabular}

Note: This table states the degree of internationalisation per continent. It is calculated by calculating the top 20 insurance company's degree of internationalisation (percentage of insurers' total GWP from home, region or world) for each continent, weighted by GWP. Values add up to 100 per cent.

Source: Authors' calculations based on annual reports. See Schoenmaker and Sass (2014) for detailed figures of individual insurers.

have income from Europe or America. It appears that the largest insurers from Asia write almost all of their GWP in the home country. Insurers such as Japan Post, Nippon Life, Ping An Insurance and Life Insurance Corporation of India write more than 98 per cent of their premiums at home.

In America, the largest insurers come from the U.S and Canada (both North America). Results here are more diverse than in Asia, although still a majority of the insurers are very locally oriented. Insurance groups such as Wellpoint Inc., United Health Group Inc. and Humana Inc. write more than 95 per cent of their premiums in the home country. More internationally oriented insurance groups are Prudential of America, MetLife and American International Group (AIG), which wrote 77, 35 and 30 per cent, respectively, of their premiums abroad in 2012.

Table 7 provides an overview of the weighted average premiums from the three continents. In Asia, 96 per cent of the premiums are written at home. This percentage has remained stable over the years and has even increased slightly from 95 to 96 per cent in 2012. The share of premiums from world and region are both only 2 per cent in Asia. This is in line with research from $\mathrm{EY},{ }^{26}$ which finds little internationalisation in the Chinese Insurance Market. Findings from Asia are in contrast with the current trend in Europe where an increasing amount of written premiums is coming from abroad. In Northern America the share of domestic written premiums is 78 per cent in 2012. This is less than in Asia but more than in Europe.

Next, Figure 9 shows that the International share of GWP is more volatile in North America than in Asia or Europe (see also Table 8). In North America, two peaks in internationalisation can be identified namely in 2005-2006 and in 2010-2011. This volatility cannot be identified in Europe, where the international share has increased from 50 per cent

\footnotetext{
${ }^{26} \mathrm{EY}(2014)$
} 


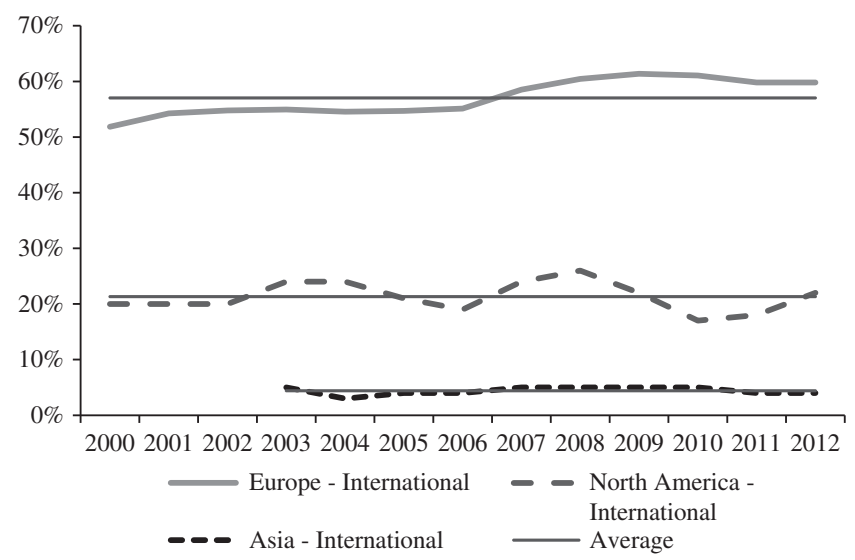

Figure 9. Comparison of internationalisation of top 20 insurers across continents.

Note: This graph shows the difference in the degree of internationalisation between Europe, North America and Asia. The degree of internationalisation is the percentage of insurers' GWP earned abroad and is calculated by taking the values for the top 20 biggest insurers, measured by GWP, and by weighting it with the amount of GWP. For Asia, data before 2002 are scarce and are thus not included. Straight horizontal lines represent the average of the available period.

Source: Table 7.

Table 8 Descriptive statistics

\begin{tabular}{lcccccccc}
\hline Variable & Mean & Minimum & Maximum & Std dev. & Skewness & Kurtosis & Jarque-Bera & Prob. \\
\hline Europe international & 0.562 & 0.520 & 0.603 & 0.029 & 0.062 & 1.514 & 1.205 & 0.547 \\
Europe region & 0.322 & 0.300 & 0.360 & 0.017 & 0.844 & 3.344 & 1.607 & 0.447 \\
Europe global & 0.240 & 0.200 & 0.270 & 0.023 & -0.452 & 1.797 & 1.226 & 0.541 \\
N-America international & 0.213 & 0.170 & 0.260 & 0.027 & 0.126 & 2.070 & 0.503 & 0.777 \\
N-America region & 0.086 & 0.030 & 0.130 & 0.038 & -0.153 & 1.358 & 1.511 & 0.470 \\
N-America global & 0.127 & 0.080 & 0.190 & 0.031 & 0.379 & 2.337 & 0.549 & 0.760 \\
Asia international & 0.044 & 0.030 & 0.050 & 0.007 & -0.659 & 2.372 & 0.886 & 0.642 \\
Asia region & 0.021 & 0.010 & 0.030 & 0.006 & 0.077 & 3.302 & 0.048 & 0.976 \\
Asia global & 0.023 & 0.020 & 0.030 & 0.005 & 0.873 & 1.762 & 1.909 & 0.385 \\
\hline
\end{tabular}

Note: This table reports the mean, minimum and maximum values for every variable used in regression models. Also it reports the standard deviation and normality measures such as the skewness, kurtosis and Jarque-Bera statistic.

in 2000 to almost 60 per cent in 2012, nor in Asia, where the share of internationally written premiums has remained stable at around 5 per cent over the years. Figure 9 indicates with the straight horizontal lines that the average premiums written abroad during the 2000-2012 period is 4 per cent in Asia, 21 per cent in North America and 57 per cent in Europe. These findings are in line with Lloyds. ${ }^{27}$

One could argue that it is inappropriate to compare the regional segment from Europe with that of North America. As the U.S. is larger than the individual European

\footnotetext{
${ }^{27}$ Lloyds (2012).
} 
countries in terms of geographical size, it may be more appropriate to classify European countries in the same way as states are classified in the U.S. For instance, if an insurer from California writes insurance in Nevada, it would count as home GWP, while a premium that is written by a French insurer in Belgium would be classified as regional. In both cases the geographical distance is comparable. To correct for this bias, we add home and regional insurance premiums in Europe to compare these with home premiums from North America (most insurers are from the U.S.). Table 7 reports that the largest insurance companies from North America are still more domestically oriented at 78 per cent than the European insurers with combined home and regional premiums at 73 per cent in 2012 .

\section{Testing for trends in internationalisation}

In order to test whether the international share of GWP of insurers has increased, and whether this trend is significant, we apply Tobit regression models. Table 8 shows the descriptive statistics of the (dependent) variables used in our regressions models. As can be obtained from the Jarque-Bera normality test, all variables are normally distributed.

Table 9 shows the test results of the Tobin regression models for European insurers (regressions in 1 to 3 ). Both the regional share and global share show an upward trend, although, for the global share, only at a 10 per cent significance level. This means that European insurers have significantly increased their cross-border share of GWP, in particular at the regional level within Europe, and confirms $\mathrm{H} 1$ and $\mathrm{H} 2$. The international share, adding up regional and global share, also experienced a significant upward trend from 2000 until 2012 and thus proves H3. Interpreting the results, it can be concluded that insurers write less and less domestic premium and thus are getting more internationally oriented.

Next, Table 9 shows the regression results for North America and Asia. In none of the regressions 4-9 is the trend coefficient statistically significant. We can thus conclude that with available data, no significant trend of internationalisation can be concluded for the largest insurers from North America and Asia. Therefore, we reject the hypotheses $(\mathrm{H} 1, \mathrm{H} 2$ and H3) for North American and Asian insurers.

The overall picture is that the largest 20 insurance groups in Europe write relatively more of their premiums abroad than their North American and Asian counterparts. Europe is thus the most internationalised region, with a still increasing share of international premium. The international outlook of European insurers may have been spurred by the creation of the EU Single Market and the introduction of the euro, as the regional share is higher than the global share for European insurers. By contrast, the global share is higher than the regional share for North American and Asian insurers. Our findings are in line with earlier research by van der Zwet $^{21}$ and Schoenmaker et al., ${ }^{25}$ who find that European insurance groups have a stronger international presence than their American or Asian peers.

In particular, large insurers in Europe are very internationally oriented with about 58 per cent of their GWP written abroad in 2012, that is, 32 per cent in the region and 26 per cent in the rest of the world. Since 2000, these insurers have significantly increased their international presence from 54 to 58 per cent and the percentage of GWP written both inside and outside of Europe has increased over the full 2000-2012 period. Maybe somewhat surprisingly, the 2008-2009 global financial crisis has not lead to a reduction of internationalisation. 
Table 9 Regression results for trend in cross-border insurance

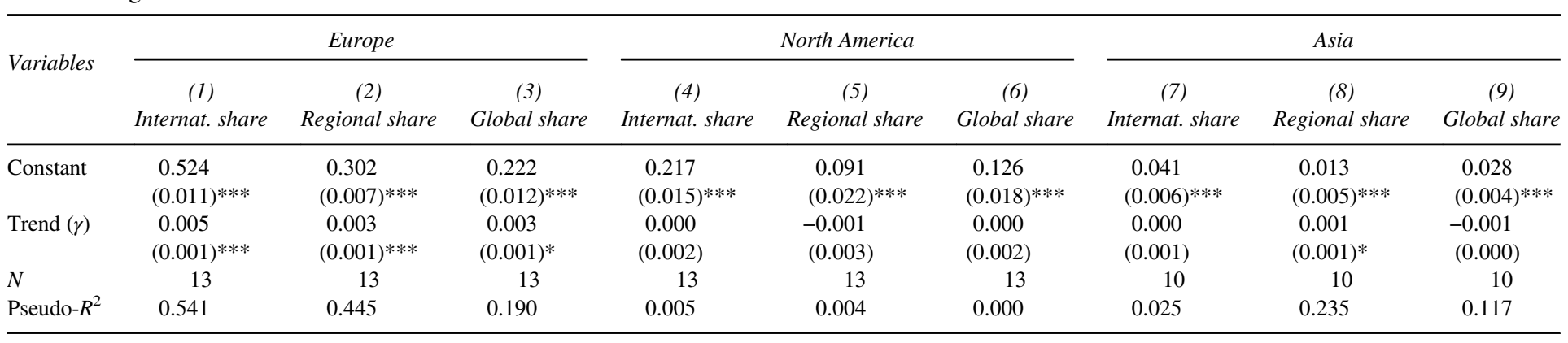

Note: The table reports Tobit regression coefficients. * significant at 10 per cent; $* *$ significant at 5 per cent; $* * *$ significant at 1 per cent. Standard errors are in brackets. 


\section{Supervisory challenges}

The nationally based supervisory system and the high and increasing degree of internationalisation of European insurance groups pose several supervisory challenges. The financial trilemma states that the three objectives of financial stability, cross-border activity and national based supervision cannot be obtained at the same time; one objective has to give. ${ }^{28}$ Given that we aim for financial stability, there is a choice between cross-border insurance and national supervision. Our results indicate that cross-border insurance is particularly advanced in Europe (at 32 per cent of total insurers' GWP) and still rising. There may thus be an increasing need for international cooperation between national insurance supervisors in Europe.

This section first identifies the challenges in the regulation and supervision of international insurance groups and then discusses the mechanisms for international cooperation. One regulatory challenge is related to foreign branches. The section "Cross-border insurance in Europe" reports that the number of branches is increasing, and certain European insurers have announced to transform (some) European subsidiaries into branches. The insurance industry is thus clearly aware of the fact that establishing branches can come with certain capital efficiencies related to the introduction of Solvency II. $^{29}$

Cross-border operations through branches also raise supervisory challenges. ${ }^{30}$ In some cases, assets from a foreign branch in a host jurisdiction can be transferred without prior approval from the supervisor. These assets can then be transferred to other parts of the group with consequences to the foreign branch's policyholders, who have no access to these assets in case of insolvency and thus face the risk of not being paid in full if claims arise. From the perspective of the host supervisor, enough assets need to be present in the host jurisdiction. Availability and transferability of assets is one of the most significant challenges in branch supervision, ${ }^{30}$ as some supervisory tools are not applicable to a branch where they are applicable to a subsidiary (which is a legal entity with a separate licence and separate capitalisation in the foreign jurisdiction). Another challenge is information asymmetry. The host supervisor may request information of the parent company of a branch in the host jurisdiction when there are doubts about the solvency of the parent. If this information is not provided on time and accurately, host supervisors cannot act in the interest of the foreign branch's policyholders. Claessens et al. ${ }^{31}$ note that home supervisors have an incentive not to tell host supervisors about emerging problems to prevent precautionary ring-fencing of assets in the host jurisdiction.

Moving to subsidiaries, the host country supervisor has control over the assets and operations of foreign subsidiaries in its jurisdiction. Nevertheless, the host country supervisor may need to rely, at least partly, on the home supervisor. A case in point is the approval of internal models under Solvency II. The design and rollout of an (international) insurance group's internal model are typically done at the head office.

Another challenge in international regulation and supervision is the level playing field. Even with a harmonised regulatory regime, supervisors may interpret the "common" rules differently or apply them differently (e.g. the application of capital add-ons in Pillar 2).

${ }^{28}$ Schoenmaker (2011).

${ }^{29}$ European Commission (2010).

${ }^{30}$ IAIS (2013).

${ }^{31}$ Claessens et al. (2010). 
Moreover, the use of directives in insurance supervision provides scope for national discretions, whereby countries can implement alternative versions of certain rules. Finally, supervisors have become more risk averse in the aftermath of the global financial crisis. They tend to require some extra capital cushion—above the regulatory minimum —at foreign (as well as domestic) subsidiaries, which is not freely available within the insurance group. Insurance groups can thus be confronted with different pockets of ring-fenced excess capital within the group, which they cannot use for the group as a whole. Cerutti and Schmieder ${ }^{32}$ provide examples of how ring-fencing can lead to extra capital needs in banking.

During the global financial crisis, the U.S. experienced the limits of state-based insurance supervision. The Dodd-Frank Reform Act has established the Federal Insurance Office (FIO). This agency is in charge of monitoring developments in the insurance industry and their contribution to systemic risk. If the latter is identified, it discusses these findings with the Financial Stability Oversight Council (FSOC). The FIO conducts its monitoring role mostly by collecting information and data from state regulators and other bodies. If an insurer is identified as systematically important, it can face higher capital requirements and tougher stress tests. Finally, the FIO is also authorised to help the Secretary of the Treasury in the negotiation of agreements that enhance prudential regulation regarding the insurance sector.

Moving to Europe, the EIOPA has a coordinating role in the supervision of international insurance groups. EIOPA takes the lead in setting secondary rules and harmonising supervisory practices across Europe, in particular with regard to Solvency II. Next, EIOPA participates in the so-called supervisory colleges of cross-border insurance groups in order to contribute to the efficient, effective and consistent functioning of these colleges and to foster coherent application of EU law among colleges. In the case of disagreement on the group internal model in the supervisory college, for example, EIOPA can give advice (Article 231 of the Solvency II Directive). Nevertheless, in the EU, final authority rests with national supervisors.

The question arises whether this coordinating role of EIOPA is sufficient for the effective supervision of large cross-border European insurance groups. In particular, the increasing share of cross-border insurance within Europe may pose a challenge for the coordination model. Game theory indicates that supervisors will not cooperate when interests diverge. ${ }^{33}$ Several examples are discussed above in this section. There are thus limits to the coordination model for supervision.

Another approach would be giving EIOPA the role as central supervisor-working with the national supervisors - in a future Insurance Union. There are several arguments in favour of centralised insurance supervision. First, large insurance groups typically apply an integrated approach to asset management. Next, Solvency II internal models will be applied group-wide. Moreover, it may be easier to assess the complexity and opacity of an insurance group as a whole as central supervisor than through supervisory colleges. Group supervision may thus be more effective as well as efficient. Finally, centralised supervision may be an effective answer to level playing field issues. Some supervisors are tougher than others, for example, on models or capital levels (a case in point is the application of capital add-ons in Pillar 2). An unlevel playing field is not always visible, as one supervisor may, for example,

\footnotetext{
${ }^{32}$ Cerutti and Schmieder (2014).

${ }^{33}$ Claessens et al. (2010).
} 
apply more conservative rules for valuations or more restrictive assumptions for models than another supervisor. ${ }^{3}$

But there are equally strong arguments against centralisation. First, insurance is less subject to systemic risk and thus less hounded by (cross-border) externalities. Cross-border externalities in banking have been a major driver of the Banking Union. ${ }^{28}$ Next, insurance, in particular for retail clients and SMEs, is local business, as products are attuned to national tax and social security laws. More broadly, the national legal setting (e.g. liability law) is important for insurance products.

\section{Conclusions}

The use of a new data set allows us to provide a comprehensive overview of cross-border insurance in Europe. The empirical findings suggest a high degree of cross-border penetration in European insurance. Moreover, the degree of internationalisation is still on the rise.

At the country level, 36 per cent of GWP comes from abroad in the EU. Of this 36 per cent, 29 per cent is from other EU countries, while 7 per cent is from third countries (outside Europe). This strong degree of foreign penetration is higher than in banking, which has only 25 per cent of its business (measured in assets) from abroad. The dominant channel for cross-border insurance within Europe is the subsidiary form (25.5 per cent) with a minor role for branches (3.5 per cent). Nevertheless, the relative number of branches in Europe is increasing.

At the company level, 58 per cent of the GWP of the major insurers (top 25) is written abroad, both in the rest of Europe and the rest of the world. Interestingly, the world share (26 per cent) is catching up with the European share (32 per cent). Insurance is thus becoming a truly global business. Again, the large banks are less international, with 47 per cent of their assets abroad.

This high and increasing degree of internationalisation of European insurance groups pose a challenge for supervision. EIOPA, the European authority, is working according to the coordination model. This means that final authority remains with national supervisors in the EU. Game theory indicates that there are limits to the coordination model. We suggest that the increasing share of cross-border insurance may tilt the supervisory balance from coordination towards centralisation in an Insurance Union at some point.

\section{Acknowledgements}

Part of this research was done at EIOPA in Frankfurt. Jan Sass was at Duisenberg School of Finance at which he conducted this research and is now consultant at Oliver Wyman. The authors would like to thank Sandra Desson and her team for their support and aid during this research. The paper reflects the opinions of the authors and not necessarily those of EIOPA. The authors would also like to thank two anonymous referees for valuable comments and suggestions. 


\section{About the Authors}

Dirk Schoenmaker is Professor of Banking and Finance at the Rotterdam School of Management (RSM), Erasmus University, and Senior Fellow at the Brussels-based think tank Bruegel. He is also member of the Advisory Scientific Committee of the European Systemic Risk Board at the ECB and Research Fellow at the Centre for European Policy Research (CEPR). Before joining RSM, Dirk was Dean of the Duisenberg School of Finance and Deputy Director Financial Markets Policy at the Netherlands Ministry of Finance.

Jan Sass is a consultant at the Amsterdam office of Oliver Wyman. This research was conducted during his Master programme at the Duisenberg School of Finance, where he specialised in Corporate Finance and Banking. He also holds a Bachelor's degree in Economics and Business from the Erasmus University of Rotterdam. Before joining Oliver Wyman, he gained experience in the financial sector through internships in banking and private equity.

\section{References}

Berger, A.N., Demsetz, R.S. and Strahan, P.E. (1999) 'The consolidation of the financial services industry: Causes, consequences and implications for the future', Journal of Banking \& Finance 23(2/3/4): 135-194.

Cerutti, E. and Schmieder, C. (2014) 'Ring fencing and consolidated banks' stress tests', Journal of Financial Stability 11: 1-12.

Claessens, S., Herring, R. and Schoenmaker, D. (2010) A Safer World Financial System: Improving the Resolution of Systemic Institutions, Geneva Report on the World Economy No. 12, Geneva: International Center for Monetary and Banking Studies.

Claessens, S. and van Horen, N. (2014) 'Foreign banks: Trends and impact', Journal of Money, Credit and Banking 46(s1): 295-326.

De Nicoló, G., Bartholomew, P., Zaman, J. and Zephirin, M. (2004) 'Bank consolidation, internationalization, and conglomeration: Trends and implications for financial risk', Financial Markets, Institutions and Instruments 13(4): 173-217.

Eppink, D.J. and van Rhijn, B.M. (1988) 'The internationalization of Dutch insurance companies', Long Range Planning 21(5): 54-60.

Ernst \& Young (2014) 'Future directions for foreign insurance companies in China', November.

European Commission (2010) 'Impact Assessment Accompanying Document to the White Paper on Insurance Guarantee Schemes', SEC 2010 (828), p. 17.

European Commission (2014) Final Report of the Commission Expert Group on European Insurance Contract Law, Brussels: European Union.

Focarelli, D. and Pozzolo, A.F. (2008) 'Cross-border M\&A's in the financial sector: Is banking different from insurance?' Journal of Banking \& Finance 32(1): 15-29.

Geringer, J.M., Beamish, P.W. and DaCosta, R.C. (1989) 'Diversification strategy and internationalization: Implications for MNE performance', Strategic Management Journal 10(2): 109-119.

Gulamhussen, M.A., Pinheiro, C. and Pozzolo, A.F. (2014) 'International diversification and risk of multinational banks: Evidence from the pre-crisis period', Journal of Financial Stability 13: 30-43.

IAIS (2013) Issues Paper on the Supervision of Cross-Border Operations Through Branches, Basel: International Association of Insurance Supervisors, October.

Lloyds (2012) "Insurance Regulation: International Horizons", presentation at the Insurance Regulation Conference, London, 26 October.

Moshirian, F. (2006) 'Aspects of international financial services', Journal of Banking \& Finance 30(4): 1057-1064.

Moshirian, F. (2012) 'The future and dynamics of global systemically important banks', Journal of Banking \& Finance 36(10): 2675-2679. 
Ramaswamy, K., Kroeck, K.G. and Renforth, W. (1996) 'Measuring the degree of internationalization of a firm: A comment', Journal of International Business Studies 27(1): 167-177.

Schoenmaker, D. (2011) 'The financial trilemma', Economics Letters 111(2011): 57-59.

Schoenmaker, D. (2013) Post-crisis reversal in banking and insurance integration: An empirical survey, Economic Papers No. 496, DG ECFIN, European Commission, Brussels.

Schoenmaker, D., Oosterloo, S. and Winkels, O. (2008) 'The emergence of cross-border insurance groups within Europe with centralised risk management', The Geneva Papers on Risk and Insurance-Issues and Practice 33(3): 530-546.

Schoenmaker, D. and Sass, J. (2014) Cross-border insurance in Europe, Duisenberg School of Finance Policy Papers, No. 45.

Sironi, A. (2002) 'Strengthening banks' market discipline and leveling the playing field: Are the two compatible?' Journal of Banking \& Finance 26(5): 1065-1091.

Starita, M.G. and Malafronte, I. (2014) Capital Requirements, Disclosure, and Supervision in the European Insurance Industry: New Challenges Towards Solvency II, London: Palgrave Macmillan, ebook.

Stoyanova, R. and Gründl, H. (2014) 'Solvency II: A driver for merger and acquisitions?' The Geneva Papers on Risk and Insurance - Issues and Practice 39(3): 417-439.

Sullivan, D. (1994) 'Measuring the degree of internationalization of a firm', Journal of International Business Studies 25(2): 325-342.

Van der Zwet, A. (2003) The Blurring of Distinctions Between Financial Sectors: Fact or Fiction? Occasional Studies, Vol 1, No. 2, Amsterdam: De Nederlandsche Bank nv.

Weiss, G.N.F. and Mühlnickel, J. (2014) 'Why do some insurers become systemically relevant?' Journal of Financial Stability 13: 95-117. 